\title{
Identification of casein peptides interacting with polysulfone ultrafiltration membranes
}

\author{
Line Gourley ${ }^{\mathrm{a}}$, Sylvie F. Gauthier ${ }^{\mathrm{a}}$, Yves Pouliota*, Daniel Molléb, \\ Joëlle Léonil ${ }^{b}$, Jean-Louis Maubois ${ }^{\mathrm{b}}$
}

\author{
${ }^{a}$ Département de sciences des aliments et de nutrition, Centre de recherche Stela, \\ université Laval, Sainte-Foy, G1K7PA, PQ, Canada \\ ${ }^{b}$ Laboratoire de recherches de technologie laitière, Inra, 65, rue de Saint-Brieuc, \\ 35042 Rennes cedex, France
}

(Received 8 January 1998; accepted 27 July 1998)

\begin{abstract}
Polysulfone (PSf) ultrafiltration membranes can be used for the fractionation of casein hydrolysates. However, the major limiting factor of this application remains the important permeation flux decline encountered during filtration. Previous studies showed that peptide-membrane interactions could affect both the flux decline and specific rejection properties of PSf. A complementary study showed that static adsorption of casein hydrolysate on PSf modifies the surface energy parameters of the membrane. Therefore, static adsorption experiments were conducted in order to identify the adsorbed peptides which would initiate fouling of PSf membranes. The adsorption was performed under different physico-chemical conditions, namely $\mathrm{pH} 6.0,8.0$, and 10.0 , without or with addition of EDTA, followed by acidic and basic desorption of adsorbed material. Membranes of $50 \mathrm{kDa}$ (MMCO) were chosen in order to minimize the effect of steric exclusion. The material collected from desorption experiments was referred to as adsorbed peptides and were analyzed by one-line RPHPLC/mass spectrometer. The modification of physico-chemical conditions (pH/EDTA) of the solution did not influence the adsorption profile of the peptides to a large extent. However, the balance size/hydrophobicity/ charge of the peptides reflected more their adsorption behaviour in terms of attractive or repulsive interactions with the membrane. Thus, the peptides were classified in three groups according to these characteristics: I) hydrophobic peptides presenting high affinity with the membrane $(\alpha \geq 1.25)$; II) peptides presenting no specificity between total hydrolysate and membrane $(0.75<\alpha$ $<1.25)$, and III) peptides excluded from the membrane $(0.75 \leq \alpha)$ which were classified as acidic, neutral, and basic peptides. (C) Inra/Elsevier, Paris.
\end{abstract}

polysulfone / adsorption / casein peptide / identification / mass spectrometry

* Correspondence and reprints. E-mail: Yves.Pouliot@aln.ulaval.ca 
Résumé - Identification de peptides caséiques interagissant avec les membranes ultrafiltrantes de polysulfone. Les membranes d'ultrafiltration de polysulfone (PSf) peuvent être utilisées pour le fractionnement d'hydrolysats caséiques. Cependant, cette application est limitée par la chute importante des flux de perméation observée durant la filtration. Des études préliminaires ont démontré que des interactions peptide-membrane pouvaient affecter la chute du flux de perméation et les propriétés de rejet du PSf. Une étude complémentaire montrait que l'adsorption statique d'un hydrolysat de caséine modifie les paramètres énergétiques de la surface membranaire. Des travaux sur l'adsorption statique ont donc été menés afin d'identifier les peptides adsorbés pouvant initier l'encrassement des membranes de PSf, L'adsorption a été effectuée sous les conditions physicochimiques suivantes : $\mathrm{pH} 6,0,8,0$ et 10,0, avec ou sans l'ajout d'EDTA, suivi d'une désorption acide et basique du matériel adsorbé. Des membranes de $50 \mathrm{kDa}$ ont été choisies de façon à minimiser l'effet d'exclusion stérique. Les peptides adsorbés, recueillis de la désorption, ont été analysés par couplage RP-HPLC/spectromètre de masse. La modification des conditions physico-chimiques (pH/EDTA) de la solution a eu peu d'effet sur le profil d'adsorption des peptides. En revanche, la balance taille/hydrophobicité/charge des peptides influençait leur adsorption via des interactions attractives ou répulsives avec la membrane. Les peptides ont donc été classifiés en trois groupes, selon ces caractéristiques, afin d'expliquer leur affinité pour la membrane. (c) Inra/Elsevier, Paris.

polysulfone / adsorption / peptide caséique / identification / spectrométrie de masse

\section{INTRODUCTION}

Polysulfone ultrafiltration (UF) membranes are widely used in the dairy industry for the processing of whey [14] and for the pre-concentration of milk prior to cheese manufacture [17]. These membranes can also be used for the fractionation of casein hydrolysates $[5,13,25]$. However, membrane fouling constitutes the major limiting factor of this application. Previous work showed important permeation flux declines during the ultrafiltration of casein hydrolysates $[9,23,25]$. It was first hypothesized that peptides-membrane interactions could explain the low permeation flux values and the specific rejective properties of polysulfone (PSf) for charged and hydroxylated amino acids. Pouliot et al. [24] observed that static adsorption was responsible for more than $70 \%$ of the water flux decline; however, this study was performed with whey protein.

A subsequent study on the effect of static adsorption on the surface properties of PSf by means of contact angle measurements [8] showed that adsorption of casein pep- tides onto PSf membranes induced changes in surface energy parameters of the membranes. Specifically, it was found that the high degree of orientation of water molecules at the surface of polysulfone membranes leads to an unstable hydration layer which promotes adsorption. It was found that static adsorption increased the dipole concentration at the surface of the newly formed membrane. In addition, it was suggested that adsorption would involve hydrophobic interactions between polysulfone and peptidic material.

It is generally accepted that specific interactions can occur between components of the solutions and the membrane materials, leading to the modification of the surface of the filtration membrane. It is known that interactions of proteins at interfaces lead to modification of the properties of the surfaces, and alter also physico-chemical and biological properties of the molecules [11]. In membrane system, such interactions are typically referred to as membrane fouling. Different approaches can be used in order to characterize membrane fouling. The classical approach remains the widely used 
method of determining the selectivity of the membranes by measuring permeation fluxes and transmission of solutes $[2,9,18,22$, 26]. Alternative methods are based on contact angle measurements on clean and fouled membranes [8], or on the determination of partition coefficients of the molecules on the membrane material by liquid chromatography (LC and HPLC) [3, 28]. The use of other methods like microscopy [7] provide information on the extent of fouling by measuring the changes in morphology of the surfaces.

However, these methods usually provide indirect informations concerning the interactions and are complementary to the identification of adsorbed material from complex solutions. Thus, the aim of the present study was to identify the casein peptides adsorbed onto the PSf material in order to determine the nature of the interactions occuring between PSf membranes and the peptidic components of a casein hydrolysate. The adsorption was performed under different physico-chemical conditions, namely $\mathrm{pH} 6.0,8.0$, and 10.0, with or without addition of EDTA, followed by acidic and basic desorption of adsorbed material. Membranes of $50 \mathrm{kDa}$ (MMCO) were chosen in order to minimize the effect of steric exclusion, since adsorption can modify the pore size of sieving membranes $[2,4,18,19]$. The material collected from desorption experiments was referred to as adsorbed peptides and were analyzed by one-line coupling between RP-HPLC and electrospray mass spectrometry (RP-HPLC/ESI-MS).

\section{MATERIALS AND METHODS}

\subsection{Preparation of the total hydrolysate from casein}

Commercial sodium caseinate (ICN Chemicals, Cleveland, OH, USA) was hydrolyzed as previously reported by Gourley et al. [9] using trypsin (Type III-S) from bovine pancreas (Sigma Chemical Co., Saint-Louis, MO, USA). The reaction was stopped by ultrafiltration of the reac- tion mixture using a $30 \mathrm{kDa}$ cut-off membrane, and the permeate was freeze-dried, constituting the casein total hydrolysate $(\mathrm{TH})$ used for the present study.

\subsection{Conditioning of polysulfone membranes}

A plate-and-frame Rayflow $2 \times 100$ module (Tech-Sep, Rhône-Poulenc, Miribel, France) equipped with a variable rotary vane pump (model 7116, Cole-Parmer Instrument Company, Chicago, IL, USA) and a temperature-controlled water bath $\left( \pm 1^{\circ} \mathrm{C}\right)$ was used for conditionning the membranes. Polysulfone (PSf) flat sheet membranes obtained from Osmonics (Minnetonka, MN, USA) were conditionned at $50^{\circ} \mathrm{C}$ by a 10 -min rinsing (once flow through), a 30 -min recirculation of $0.3 \% \mathrm{HCOOH}$, a 15 -min rinsing, a 30 -min recirculation of $0.3 \%$ $\mathrm{NaOH}$ and a final 15-min rinse. Distilled deionized water was used throughout the experiment.

\subsection{Adsorption and desorption of the peptides}

The casein total hydrolysate (TH) was solubilized in $500 \mathrm{~mL}$ distilled deionized water at $1.65 \%$ total solids $(\mathrm{w} / \mathrm{v})$. Whenever required, $20 \mathrm{mmol} \cdot \mathrm{L}^{-1}$ EDTA ([ethylenediamine]tetraacetic acid disodium salt, Fisher Scientific, Ontario, Canada) was added, and the $\mathrm{pH}$ of the solution was then adjusted to $6.0,8.0$ or 10.0 using $1 \% \mathrm{HCOOH}$ or $5 \% \mathrm{NH}_{4} \mathrm{OH}$.

The solution was poured in a stainless steel container where 10 PSf membrane sheets $\left(0.2 \mathrm{~m}^{2}\right.$ of membrane surface) were placed in a support and maintained separated with rods; the solution was in contact with the PSf for $12 \mathrm{~h}$. Then, the membranes were soaked in $1 \mathrm{~L}$ distilled deionized water in order to remove the weakly adsorbed material, and the water was discarded afterward; the $\mathrm{pH}$ of rinsing water was adjusted to that of the adsorption.

A sequence of acidic and basic desorption of the peptides was performed. The membranes were first soaked for $12 \mathrm{~h}$ in $500 \mathrm{~mL}$ of water at $\mathrm{pH} 3.0(\mathrm{HCOOH})$, followed by a second soaking of $12 \mathrm{~h}$ in an equal volume of water at $\mathrm{pH} 11.0$ $\left(\mathrm{NH}_{4} \mathrm{OH}\right)$. The acidic and basic solutions obtained were partially evaporated with a Rotavapor in order to remove volatile compounds. A 
preliminary analysis by RP-HPLC revealed that the acidic and basic samples were similar in terms of peptidic peaks. Therefore, the two solutions were pooled and freeze-dried. The pooled samples containing adsorbed peptides were further analysed by one-line RP-HPLC/ESI-MS.

\subsection{Identification of the peptides adsorbed on PSf membranes}

\subsubsection{RP-HPLC analyses}

HPLC was performed using an apparatus from Waters (625 LC System, Millipore, Waters, Milford, MA, USA) equipped with a 600E System Controller and a 911 Photodiode Array detector. The apparatus was equipped with an analytical RP column, Symmetry ${ }^{\mathrm{TM}} \mathrm{C}-18$ column $(125 \times 2.1 \mathrm{~mm}$ id; Waters, Milford, MA, USA). Samples were dissolved ( $5 \mathrm{mg}: 1 \mathrm{~mL}$ ) in Milli Q water (Millipore, F-78051 Saint-Quentin-enYvelines, France) containing $0.2 \%$ trifluoroacetic acid (TFA; Pierce, Touzart et Matignon, France). Two buffers, A containing $1.06 \%$ TFA in Milli Q water and B containing $0.1 \%$ TFA and $80 \%$ acetonitrile (Merk, F-94736 Nogent- sur-Marne, France) in Milli Q water, were used for the elution. A linear gradient was performed as follows: $100 \% \mathrm{~A}$ for $5 \mathrm{~min}, 50 \% \mathrm{~B}$ in $75 \mathrm{~min}, 80 \% \mathrm{~B}$ in $10 \mathrm{~min}, 80 \% \mathrm{~B}$ for $2 \mathrm{~min}$, and $100 \% \mathrm{~A}$ in $2 \mathrm{~min}$. At a flow rate of $0.25 \mathrm{~mL} \cdot \mathrm{min}^{-1}, 100 \mu \mathrm{g}$ or $5 \mathrm{mmol}$ sample was injected onto the column, maintained at $40{ }^{\circ} \mathrm{C}$, and the absorbance was measured at 214 and $280 \mathrm{~nm}$. Chromatographic data were further transformed and analyzed with a 900 Series Intelligent Interface Nelson (Stang Instruments, F-93320 Les Pavillons sous Bois, France).

\subsubsection{Electrospray mass spectrometry}

The MS analysis of casein peptides was performed by an on-line RP-HPLC/ESI-MS. Samples were initially separated by RP-HPLC according to the elution conditions described above. Eluted peaks were detected by absorbance at 214 and $280 \mathrm{~nm}$, and by total ion current (TIC). The mass spectrometer API $\mathrm{III}^{+}$(Sciex, Thornill, Canada) was a triple quadrupole MS equipped with an atmospheric pressure ionization ion source. Multiply charged peptide ions were generated by spraying the sample solution through a stainless steel capillary held at high potential. The voltage in the sprayer was usually set at $5 \mathrm{kV}$ for positive ion production. A coaxial air flow along the sprayer was provided to assist liquid nebulization. The nebulizer pressure was usually adjusted in the range $0.3-0.4 \mathrm{MPa}$. For the on-line RP-HPLC/ESI-MS analysis, splitting of the liquid flow was achieved by zero-dead-volume connection, and the column effluent was diverted to the MS ( $15 \%$ of the effluent) and to the UV detector ( $85 \%$ of the effluent). This arrangement permitted a straightforward correlation of the TIC trace with the UV trace. The connection between the HPLC system and the ion source was a fused silica capillary of $75 \mu \mathrm{m}$ id. The interface between the sprayer and the mass analyser consisted of a small conical orifice of $100 \mu \mathrm{m}$ diam, and in our experiments the voltage was set at $70-90 \mathrm{~V}$. A gas curtain formed by a continuous flow $\left(0.8-1.2 \mathrm{~L} \cdot \mathrm{min}^{-1}\right)$ of nitrogen in the interface region served to break up any clusters. The instrument mass-to-charge $(\mathrm{m} / \mathrm{z})$ scale was calibrated with propylene glycols. All peptide mass spectra were obtained from the signal averaging of multiple scans. Each scan was acquired over the range of $\mathrm{m} / \mathrm{z}$ values from 400 to 2400 using a step size of $0.3 \mathrm{Da}$ and a dwell time of $0.5 \mathrm{~ms}$. Molecular masses were determined from the measured $\mathrm{m} / \mathrm{z}$ values for the protonated molecules. Results were acquired on an Apple Macintosh computer and processed using the software package Mac Spec 3.2 Sciex (Sciex, Thornhill, Canada).

Assignment of individual sequences from the molecular masses of peptides was based on: i) the known sequence of bovine caseins, arising from Holstein cows, whose milk contains the main genetic variants $\alpha_{\mathrm{s} 1} \mathrm{~B} 97 \%, \alpha_{\mathrm{s} 2} \mathrm{~A}$ $100 \%, \beta A^{1} 53 \%, \beta A^{2} 45 \%, \kappa A 71 \%$ and $\kappa B$ $29 \%$ according to Grosclaude [10], and ii) the presence of a tryptic and/or chymotryptic cleavage site at either end of the sequence, which was considered as a precondition. Assignment of individual sequences was assisted by the use of the Mac Bio Spec data base. The maximum error between observed and calculated (theoretical) masses in our study never exceeded $0.07 \%$. The mass assignment was confirmed by amino acid sequence determination using tandem mass spectrometry (MS-MS) analysis.

The peaks collected after two RP-HPLC separations were evaporated using a Speed-Vac concentrator (Bioblock, Paris, France) and solubilized in Milli Q water $60 \%$ : acetonitrile $40 \%$ : formic acid $0,1 \%$ : TFA $0.05 \%$, and were continuously infused with a pump model 22 (Harvard Apparatus, South Natik, MA, USA) at a flow rate of $3 \mu \mathrm{L} \cdot \mathrm{min}^{-1}$. Collision-assisted dissociation 
experiments in the collision quadrupole $\left(\mathrm{Q}_{2}\right)$ region were performed using argon with collision energies ranging from 30 to $60 \mathrm{eV}$. The product ion mass spectra were acquired by scanning the third quadrupole $\left(\mathrm{Q}_{3}\right)$ while the first $\left(Q_{1}\right)$ was set for transmitting the precursor ion. Both analysing quadrupoles $Q_{1}$ and $Q_{3}$ were operated at a resolution of unit $\mathrm{m} / \mathrm{z}$ ratio. For peptides with molecular mass over $2400 \mathrm{Da}$, multiply protonated species were generated by electrospray ionization with predominance of $[\mathrm{M}+3 \mathrm{H}]^{3+}$ and $[\mathrm{M}+2 \mathrm{H}]^{2+}$ ions. The product ion spectra was obtained by collision-assisted dissociation of these ions which produced several diagnostic fragment ions. This fragmentation spectra was sufficient for assignment of the peptide from its known molecular mass and from a laboratory-made data bank of all primary sequences of caseins. Indeed, with the high accuracy on the molecular mass of the peptide, the 'sequence tag' obtained by MS-MS allowed to found the sequence of the parent peptide.

\subsection{Calculations}

The distribution of peptides between the bulk solution (TH) and material adsorbed onto the membrane surface was characterized using partition coefficients calculated as follows:

$$
=\frac{C_{m}}{C_{b}}
$$

where $\mathrm{C}_{\mathrm{m}}$ and $\mathrm{C}_{\mathrm{b}}$ are the proportion of peptides in the adsorbed material (m) and in TH (b) as determined by the relative surface area of peptidic peaks from chromatographic profiles obtained by RP-HPLC.

The amino acid sequences of the peptides were determined, as indicated by the MS analyses, from the following genetic variants of caseins: $\beta \mathrm{A}^{1}, \alpha_{\mathrm{s} 1} \mathrm{~B}, \alpha_{\mathrm{s} 2} \mathrm{~A}$, and $\kappa \mathrm{A}$, according to Swaisgood [27]. The calculation of isoelectric point and hydrophobicity of the peptides was performed with the use of a program provided by the Institut de recherche INRA (Rennes), based on Bigelow [1] and Tanford [29]. The net charge of the peptides, at the three $\mathrm{pH}$ under study, was determined with the pKa values of the amino acids considering that the side chain of histidine at $\mathrm{pH} 6.0$ and that of tyrosine at $\mathrm{pH} 10.0$ are neutral, while the side chain of lysine is positively charged, as well as is the $\alpha-\mathrm{NH}_{2}$ of the peptidic chain. However, it should be considered that at $\mathrm{pH} 6.0$ the His becomes partially positive, whereas at $\mathrm{pH} 10.0 \mathrm{Tyr}$ is partially negative, and Lys and the $\alpha-\mathrm{NH}_{2}$ are partially neutral; these modifications in the net charge of the peptide can impart a different behaviour to the molecules.

\subsection{Principal component analysis}

Principal component analysis [16] was performed in order to classify the peptides according to their characteristics, namely molecular mass, hydrophobicity, and charge, with SAS 6-12 software (SAS Institute Inc., Cary, NC).

\section{RESULTS}

\subsection{Characterization of the total hydrolysate}

The chromatographic profile (figure 1) obtained from RP-HPLC analysis of the casein total hydrolysate (TH) showed the occurrence of over 80 peptidic peaks, representing 180 identified molecular masses. Therefore, only the major peaks (OD $>0.1$ AU/FS) were individually collected for their identification by mass spectrometry (MS/MS), and their characteristics are shown in table I. These data illustrate that the hydrolysate from casein was composed of a large range of peptides differing in molecular mass (490 to $5360 \mathrm{kDa}$ ), charge $(-5$ to +1$)$, pI (4.1 to 10.2$)$, and hydrophobicity ( 4 to $\left.73 \mathrm{kcal} \cdot \mathrm{mol}^{-1}\right)$. The trypsin (type III-S) used in this study contained also chymotrypsin; the peptides obtained were formed with a high proportion $(17 \% \mathrm{~N}$-terminal and $24 \%$ C-terminal) of chymotrypsin cleavage sites, giving the $\mathrm{TH}$ a different character than an hydrolysate obtained with purified trypsin.

\subsection{Characterization of adsorbed peptides}

Mass spectrometry analyses (LC/MS) revealed that each peptide identified in the $\mathrm{TH}$, except the peptide $1-25$ from $\beta$-casein (no 32), was also found in the adsorbed 


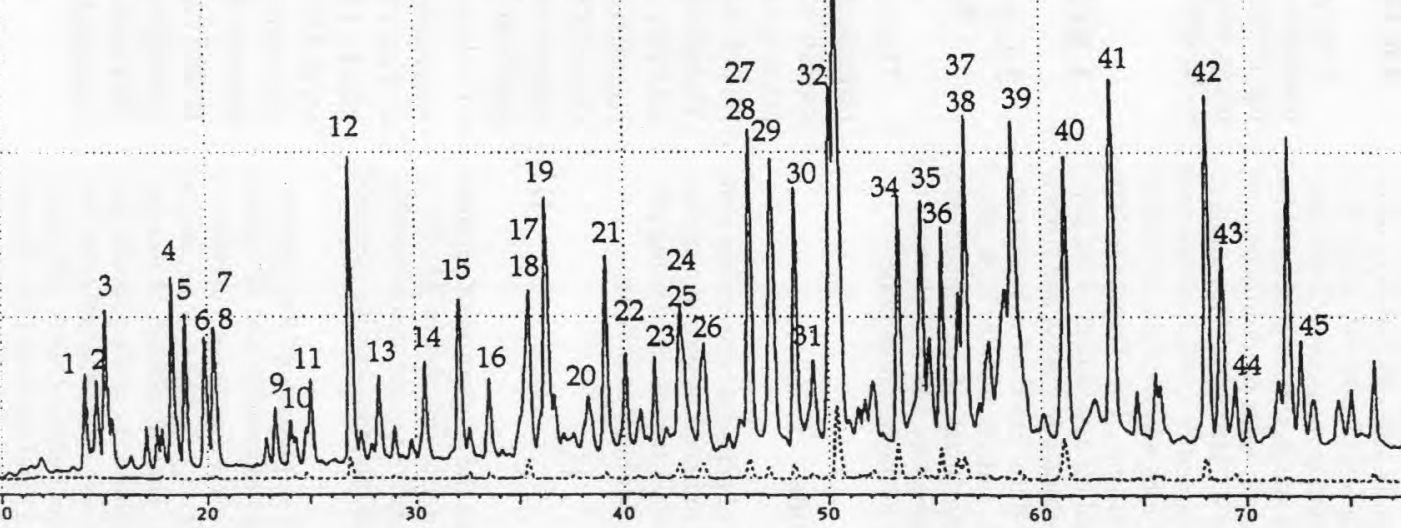


Table I. Characteristics of the peptides in the casein total hydrolysate (TH), identified by mass spectrometry.

Tableau I. Caractéristiques des peptides de l'hydrolysat total de caséine (HT), identifiés par spectrométrie de masse.

\begin{tabular}{|c|c|c|c|c|c|}
\hline $\begin{array}{l}\text { Peak } \\
\text { Number }^{1}\end{array}$ & $\begin{array}{l}\text { Peptidic } \\
\text { sequence }\end{array}$ & $\begin{array}{l}\text { Molecular } \\
\text { Mass }^{2} \\
\text { (Dalton) }\end{array}$ & $\begin{array}{l}\text { Hydrophobicity } \\
\left(\mathrm{kcal} \cdot \mathrm{mol}^{-1}\right)\end{array}$ & $\mathrm{pI}$ & $\begin{array}{c}\text { Net } \\
\text { Charge } \\
\text { at } \mathrm{pH} 8.0\end{array}$ \\
\hline 1 & $\alpha_{\mathrm{s} 1} 80-83$ & 525 & 4.5 & 9.4 & +1 \\
\hline 2 & $\beta^{s 1} 164-169$ & 649 & 3.9 & 9.4 & +1 \\
\hline 3 & $\alpha_{s 1} 4-7$ & 494 & 7.1 & 9.4 & +1 \\
\hline 4 & $\alpha_{\mathrm{s} 1} 125-132$ & 910 & 5.2 & 7.0 & 0 \\
\hline 5 & $\beta 100-105$ & 646 & 6.9 & 6.2 & 0 \\
\hline 6 & $\alpha_{\mathrm{sl}} 120-124$ & 615 & 5.2 & 9.4 & +1 \\
\hline 7 & $\alpha_{\mathrm{s} 1} 84-90$ & 831 & 5.1 & 4.1 & -2 \\
\hline 8 & $\alpha_{\mathrm{s} 1} 37-42$ & 689 & 5.6 & 6.2 & 0 \\
\hline 9 & $\alpha_{\mathrm{s} 1}^{\mathrm{s1}} 35-42$ & 947 & 7.1 & 6.2 & 0 \\
\hline 10 & $\kappa 1-10$ & 1253 & 6.3 & 4.1 & -2 \\
\hline 11 & $\alpha_{\mathrm{s} 1} 80-90$ & 1338 & 9.5 & 5.4 & -1 \\
\hline 12 & $\beta^{s 177-183}$ & 830 & 11.3 & 9.0 & +1 \\
\hline 13 & $\kappa 17-21$ & 643 & 6.8 & 6.3 & 0 \\
\hline 14 & ק 33-48 & 2063 & 7.0 & 4.1 & -5 \\
\hline 15 & ß 170-176 & 781 & 12.5 & 9.4 & +1 \\
\hline 16 & $\alpha_{\mathrm{s} 2} 200-203$ & 491 & 10.1 & 5.8 & 0 \\
\hline 17 & $\beta 49-52$ & 513 & 8.2 & 7.0 & 0 \\
\hline 18 & $\alpha_{c_{2}} 189-193$ & 632 & 9.2 & 9.4 & +1 \\
\hline 19 & 队 $108-113$ & 748 & 10.7 & 6.2 & 0 \\
\hline 20 & $\alpha_{\mathrm{s} 2} 138-149$ & 1467 & 10.2 & 4.1 & -2 \\
\hline 21 & $\alpha_{\mathrm{s} 2} 115-125$ & 1196 & 14.7 & 10.2 & +1 \\
\hline 22 & $\kappa 98-105$ & 971 & 10.3 & 7.0 & 0 \\
\hline 23 & $\alpha_{\mathrm{s} 2} 81-91$ & 1369 & 13.1 & 6.2 & 0 \\
\hline 24 & $\alpha_{\mathrm{s} 1} 106-119$ & 1662 & 15.5 & 4.1 & -2 \\
\hline 25 & $\kappa 25-30$ & 796 & 14.2 & 5.8 & 0 \\
\hline 26 & $\kappa 35-43$ & 1140 & 16.4 & 5.8 & 0 \\
\hline 27 & $\alpha_{\mathrm{s} 1} 104-119$ & 1953 & 19.8 & 4.1 & -1 \\
\hline 28 & $\alpha_{\mathrm{s} 2} 92-98$ & 958 & 13.4 & 5.8 & 0 \\
\hline 29 & $\beta^{52} 184-190$ & 821 & 10.3 & 4.1 & -1 \\
\hline 30 & ß 191-202 & 1384 & 19.4 & 6.2 & 0 \\
\hline 31 & $\alpha_{\mathrm{s} 2} 174-181$ & 980 & 15.2 & 9.0 & +1 \\
\hline 32 & $\beta 1-25$ & 3124 & 21.1 & 1.7 & -5 \\
\hline 33 & $\alpha_{\mathrm{s} 1} 194-199$ & 748 & 10.2 & 5.8 & 0 \\
\hline 34 & $\alpha_{\mathrm{s} 1} 152-164$ & 1547 & 17.9 & 4.1 & -1 \\
\hline 35 & $\alpha_{\mathrm{s} 1} 166-193$ & 3028 & 31.9 & 4.1 & -3 \\
\hline 36 & $\alpha_{\mathrm{s} 1} 152-165$ & 1710 & 20.7 & 4.1 & -1 \\
\hline 37 & $\alpha_{\mathrm{s} 2} 99-113$ & 1771 & 23.7 & 6.3 & 0 \\
\hline 38 & $\alpha_{\mathrm{s} 1} 165-193$ & 3191 & 34.8 & 4.1 & -3 \\
\hline 39 & ק 203-209 & 742 & 15.5 & 5.8 & 0 \\
\hline 40 & $\alpha_{\mathrm{s} 1} 91-100$ & 1268 & 16.1 & 6.2 & 0 \\
\hline 41 & $\alpha_{s 1}^{23-34}$ & 1385 & 21.5 & 6.2 & 0 \\
\hline 42 & $\alpha_{\mathrm{s} 1} 133-151$ & 2318 & 28.5 & 4.1 & -2 \\
\hline 43 & B 69-97 & 3115 & 43.2 & 6.2 & 0 \\
\hline 44 & $\alpha_{\mathrm{s} 2} 92-113$ & 2711 & 37.1 & 6.3 & 0 \\
\hline 45 & ß $49-97$ & 5360 & 73.0 & 7.0 & 0 \\
\hline 46 & $\beta 114-143$ & 3469 & 40.5 & 4.1 & -4 \\
\hline
\end{tabular}

${ }^{1}$ As identified in figure 5.1. ${ }^{2}$ Determined by mass spectrometry. ${ }^{3}$ Determined according to Bigelow [1] and Tanford [29]. ${ }^{1}$ Tel qu'identifié sur la figure 5.1. ${ }^{2}$ Déterminé par spectrométrie de masse. ${ }^{3}$ Déterminé selon Bigelow [1] et Tanford [29]. 
material under overall physico-chemical conditions studied ( $\mathrm{pH} 6.0,8.0$, 10.0, with or without addition of EDTA). Therefore, a quantitative analysis based on surface area of peptidic peaks was performed in order to determine differences in the adsorbed material caused by the change in physico-chemical conditions of the solution. Figure 2 illustrates the partition coefficients $(\alpha)$ of the peptides between bulk solution (TH) and material adsorbed onto the membrane (equation 1); the peptides are numbered as in table $I$, and are presented in increasing order of hydrophobicity. A value of $\alpha=1.00$ indicates an equal affinity of the peptide for the membrane and for the solution, $\alpha>1.00$ suggests a stronger affinity of the peptides for the membrane surface, whereas $\alpha<1.00$ represents peptides excluded from membrane surface,

It can be observed from figure 2 that $\alpha$ generally increased with the hydrophobicity of the peptide. For example, the peptide no 2 was weakly adsorbed onto the membrane and possesses the lowest hydrophobic character $\left(3.9 \mathrm{kcal} \cdot \mathrm{mol}^{-1}\right)$, whereas the peptide no 45 ( $\beta$ 49-97) including 12 Pro and possessing the highest degree of hydrophobicity $\left(73 \mathrm{kcal} \cdot \mathrm{mol}^{-1}\right)$ also presented the highest $\alpha$ value. The peptide no 46 ( $\beta$ 114-143) showed a different behaviour; this peptide contains 4 Pro and is highly hydrophobic $\left(40.5 \mathrm{kcal} \cdot \mathrm{mol}^{-1}\right)$ but possessed a low $\alpha$ value. However, the behaviour of this peptide can be explained by the presence of several negative charges $(-4)$ along the peptidic chain which are repulsed by the $\mathrm{O}-\mathrm{S}-\mathrm{O}$ sites onto the membrane surface. The treatments (pH/EDTA) applied to TH solution did not influence the adsorption profile to a large extent. The majority of the peptides were only slightly, but not consistently affected by the modification of the $\mathrm{pH}$. For example, a few peptides (e.g. no 36 and 42) present an increasing $\alpha$ with a decrease in $\mathrm{pH}$; these peptides contain both tyrosine and proline in their sequence, in addition to their acidic and hydrophobic character. The adsorption of some other peptides (no 23, 40 and 44) was affected by the combination of $\mathrm{pH} / \mathrm{EDTA}$ treatments. Also, 9 of the 45 adsorbed peptides presented the same level of adsorption with all treatments, namely no $6,12,28,21,30,27,35,38$, and 43. Most of these peptides possess a non-polar $\mathrm{N}$-terminal aminoacid and a positive charge (Lys, Arg) at the C-terminal position; seven of these peptides contain between 1 to 7 Pro,

The peptides present in the adsorbed material were therefore classified into three groups, according to their values, namely group I corresponding to $\alpha \geq 1.25$ and referred to as adsorbed peptides, group II with $0.75<\alpha<1.25$ representing peptides with no specific affinity for the membrane or bulk solution, and group III with $0.75 \leq \alpha$ and referred to as excluded peptides. Peptides from groups I and III are presented in table $I I$, namely the adsorbed and excluded peptides, in order to correlate their physicochemical characteristics to their adsorption behaviour. The peptides from group I possess a high level of hydrophobicity (16 to $73 \mathrm{kcal} \cdot \mathrm{mol}^{-1}$ ), an hydrophobic N-extremity (aliphatic side chain or phenyl ring) and a positive charge (Lys, Arg) at the C-terminal of the molecule and are globaly neutral. Opposingly, the excluded peptides (group III) presented different characteristics, and were thus classified according to their charge (acidic, neutral, basic) and hydrophobicity (increasing order). The acidic peptides possessing at least two net negative charges were excluded from the membrane, even peptides having a relatively high degree of hydrophobicity (10 to $40 \mathrm{kcal} \cdot \mathrm{mol}^{-1}$ ). The neutral peptides of low hydrophobicity $\left(<11 \mathrm{kcal} \cdot \mathrm{mol}^{-1}\right)$ had also weak affinity with the surface of the membrane; these molecules all present a Glu in N-terminal and a Lys in C-terminal position. Finally, the group of basic peptides excluded from the membrane surface are short, positively charged molecules with very low hydrophobicity $\left(<6 \mathrm{kcal} \cdot \mathrm{mol}^{-1}\right)$. 


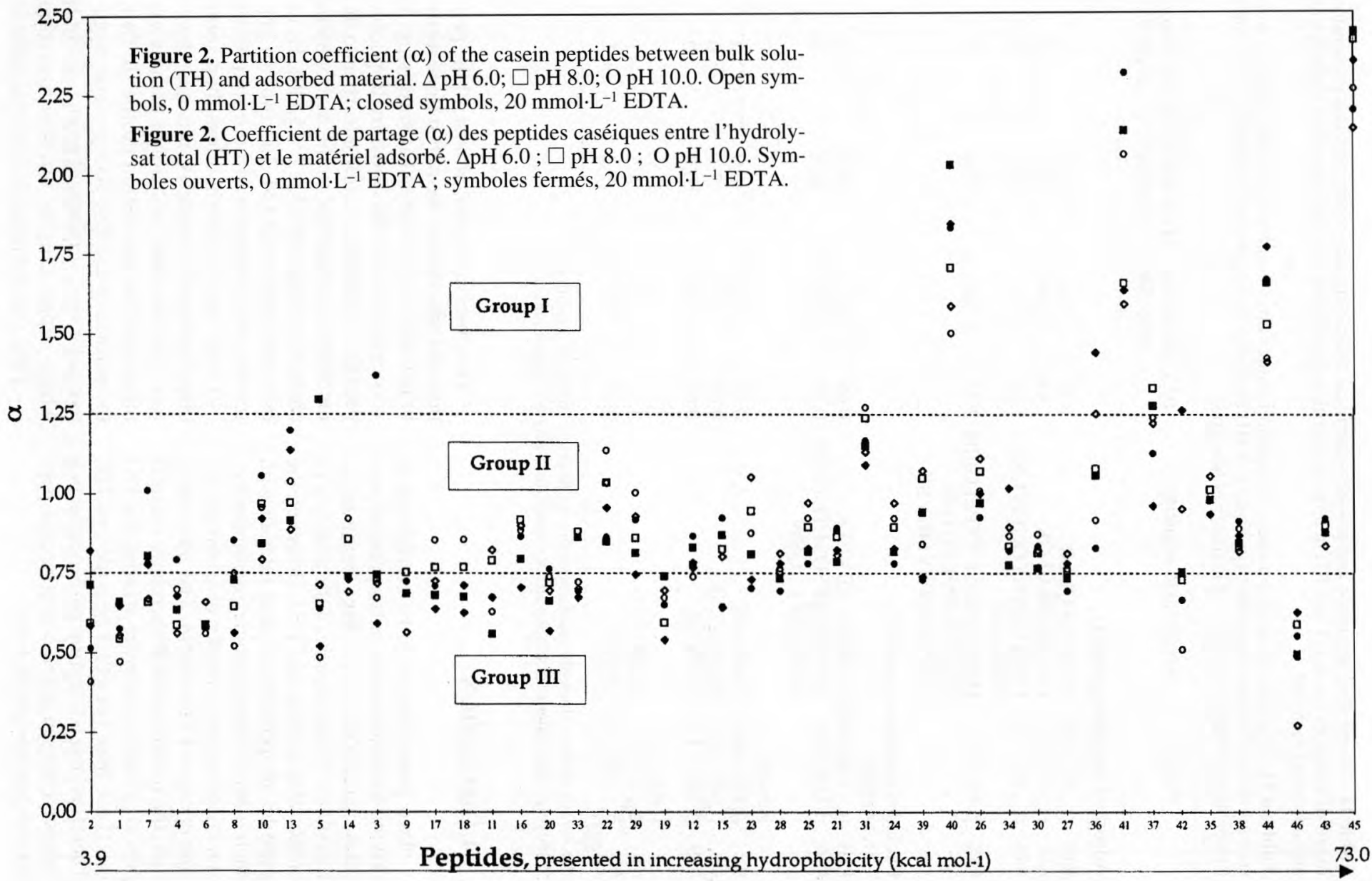


Table II. Amino acid sequence and physico-chemical characteristics of the peptides presenting major differences (groups I and III) in term of partition coefficient ( $\alpha$ ) between total hydrolysate and adsorbed material.

Tableau II. Séquence en acides aminés et caractéristiques physico-chimiques des peptides présentant des différences majeures (groupes I et III) en terme de coefficient de partage ( $\alpha$ ) entre l'hydrolysat total de caséines et le matériel adsorbé.

\begin{tabular}{|c|c|c|c|c|}
\hline Peptide & Amino acid sequence & $\alpha^{1}$ & $\begin{array}{l}\text { Molecular } \\
\text { mass (Da) }\end{array}$ & $\begin{array}{l}\text { Hydrophobicity Net charge } \\
\left(\mathrm{kcal} \cdot \mathrm{mol}^{-1}\right) \\
\text { at } \mathrm{pH} 8.0\end{array}$ \\
\hline
\end{tabular}

\begin{tabular}{|c|c|c|c|c|c|c|}
\hline \multicolumn{7}{|c|}{ Adsorbed peptides (group I) } \\
\hline \#40 & $\alpha_{\mathrm{s} 1} 91-100$ & YLGYLEQLLR & 1.76 & 1268 & 16.1 & 0 \\
\hline \#41 & $\alpha_{\mathrm{s} 1} 23-34$ & FFVAPFPEVFGK & 1.91 & 1385 & 21.5 & 0 \\
\hline \#44 & $\alpha_{\mathrm{s} 2}^{\mathrm{si}} 92-113$ & $\begin{array}{l}\text { FPQYLQYLYQGPIVLNP } \\
\text { WDQVK }\end{array}$ & 1.58 & 2711 & 37.1 & 0 \\
\hline \#45 & $\beta 49-97$ & $\begin{array}{l}\text { IHPFAQTQSLVYPFPGPIH } \\
\text { NSLPQNIPPLTQTPV } \\
\text { VVPPFLQPEVMGVSK }\end{array}$ & 2.32 & 5360 & 73.0 & 0 \\
\hline \multicolumn{7}{|c|}{$\begin{array}{l}\text { Excluded peptides (group III) } \\
\text { Acidic }\end{array}$} \\
\hline \#20 & $\alpha_{\mathrm{s} 2} 138-149$ & TVDMEUTEVFTK & 0.69 & 1467 & 10.2 & -2 \\
\hline \multirow[t]{2}{*}{ \#46 } & $\beta 114-143$ & $\begin{array}{l}\text { YPVEPFTESQSLTLTDVE } \\
\text { NLHLPLPLLQSW }\end{array}$ & 0.50 & 3469 & 40.5 & -4 \\
\hline & Neutral & & & & & \\
\hline \#5 & B 100-105 & EAMAPK & 0.72 & 646 & 6.9 & 0 \\
\hline \#9 & $\alpha, 35-42$ & EKVNELSK & 0.68 & 947 & 7.1 & 0 \\
\hline \#19 & $\beta 108-113$ & EMPFPK & 0.65 & 748 & 10.7 & 0 \\
\hline & Basic & & & & & \\
\hline \#1 & $\alpha_{\mathrm{s} 1} 80-83$ & HIQK & 0.58 & 525 & 4.5 & +1 \\
\hline \#6 & $\alpha_{\mathrm{s} 1} 120-124$ & LHSMK & 0.59 & 615 & 5.2 & +1 \\
\hline
\end{tabular}

${ }^{\alpha f}$ Average of the values obtained under the six physico-chemical conditions.

${ }^{\alpha 1}$ Moyenne des valeurs obtenues aux six conditions physico-chimiques.

\section{DISCUSSION}

Two principles are to be considered as driving forces leading to adsorption of peptides, namely the free energy being negative $(\Delta \mathrm{G}<0)$, and the size of the molecule or contactable surface area [31]. However, the peptides in solution can also interact with each other by hydrophobic and/or electrostatic interactions in order to minimize the free energy of the system. The adsorption onto the membrane will then only occur if peptides have a stronger affinity for PSf interface than for other peptides in TH. Therefore, the adsorption profile reflects a balance between peptide-peptide and peptide-membrane interactions.
The observation that almost all the peptides did adsorb onto the polysulfone membrane material is somewhat surprising. It was expected that the most hydrophobic peptides would specifically adsorb onto the membrane surface due to the hydrophobic character of the PSf $[3,12,15,30]$. However, the peptides $\beta$ 114-143 (no 46) presenting a high degree of hydrophobicity $\left(40 \mathrm{kcal} \cdot \mathrm{mol}^{-1}\right)$ adsorbed less than some other hydrophilic peptides. We must therefore consider that additional parameters influenced the adsorption profile. In fact, the surface of the PSf also presents negative polar sites (sulfonated groups, O-S-O) which impart a highly oriented hydration layer [8], and promote adsorption in order to 
minimize the energy of the system. Mostly all peptides can therefore adsorb to varying degrees depending upon their hydrophobic and/or polar properties and even by the distribution of charges along the molecule, in a manner to decrease the free energy. Consequently, the transmission of the peptide into the permeate will depend on its molecular mass togetherwith low interactions with the molecules in the adsorbed layer. However, the peptide $\beta 1-25$ was not found in adsorbed material, at any $\mathrm{pH}$. This peptide possesses 5 net negative charges, a positive charge at each end of the molecule, and has 4 phosphoseryl residues (Ser-P) and only one aromatic within its chain; these characteristics give the peptide a strong polar character that could stabilize the molecule in aqueous system in addition to the repulsive effect of negative charges with electronegative sites onto the membrane. The behaviour of this peptide corresponds to the observations reported by Nau [20], where $95 \%$ of the fragment $\beta 1-25$ was retained by a $10 \mathrm{kDa}$ PSf membrane, despite its 3130 Da molecular mass.

The classification of peptides according to their adsorptive behaviour (table II) suggests that the molecules within the same class share more than one characteristic, namely molecular mass, hydrophobicity and charge. A more detailed examination of highly adsorbed species (group I) reveals that these neutral peptides have relatively high molecular masses ( $1268-5360 \mathrm{kDa}$ ) and possess hydrophobic sites along the peptidic chain, and a positively charged C-terminal amino acid (Lys, Arg) together with a non-polar amino acid at $\mathrm{N}$-terminal. For example, the peptide $\alpha_{\mathrm{s} 2} 92-113$ (no 44) with a phenylalanine ( $\mathrm{N}$-terminal) and a lysine (C-terminal) and 8 aromatics along the 22 amino acids peptidic chain, possesses a hydrophobicity of $37 \mathrm{kcal} \cdot \mathrm{mol}^{-1}$ and a net charge of zero. Thus, this peptide is endowed with some characteristics that can promote adsorption onto the PSf surface via hydrophobic (bisphenol and methyl groups) sites of the membrane material. The frag- ment $\beta-\mathrm{CN} 49-97$ showed a similar adsorption profile. Daufin et al. [6] reported a high unexpected retention of this peptide under an electric field owing the behaviour of highly hydrophobic peptides to their molecular mass and charge, which is in agreement with our results. In addition, a study conducted by Bouhallab and Henry [2] on the transmission of the $\beta-C N$ 193-209 resulted in a reduction in adsorption rate and a significant increase in the transmission of this neutral hydrophobic peptide in the presence of a hydrophobic peptides mixture. Therefore, hydrophobic interactions at the membrane surface and in the media are to be considered in the determination of the peptides behaviour.

Among the peptides excluded from the membrane material (table $I I$ ) is a group of acidic molecules (no 20 and 46) possessing the size (1 467-3 469 Da) and hydrophobicity $\left(10-40 \mathrm{kcal} \cdot \mathrm{mol}^{-1}\right)$ for adsorption to occur; however, they possess a net negative charge of -2 or -4 which causes repulsion with polar negative components (O-S-O) of the membrane surface. Within this group, the peptide $\beta$ 114-143 (no 46) is composed of 30 amino acids (3 $469 \mathrm{Da}$ ), has a high degree of hydrophobicity (41 kcal $\cdot \mathrm{mol}^{-1}$ ) but has a net charge of -4 , which is highly repulsive with the membrane. Therefore, the combined effect of charge, hydrophobicity and size appears to be determinant in the nature of the interaction (attractive or repulsive) with the membrane surface. This view supports the observations of Pouliot et al. [25] suggesting that non-polar amino acids were not selectively rejected by the membrane and that the charge/hydrophobicity balance of the peptides is the predominant factor determining the fractionation of casein hydrolysates.

The excluded peptides with neutral or basic properties involve short molecules (maximum of 8 amino acids). The neutral peptides could interact with the membrane but these molecules have a low degree of hydrophobicity $\left(<11 \mathrm{kcal} \cdot \mathrm{mol}^{-1}\right)$ in addi- 
tion to their zero net charge. However, they possess very close opposite charges $\left(\mathrm{Glu}^{(-)}\right.$ at $\mathrm{N}$-terminal and $\mathrm{Lys}^{(+)}$at C-terminal), on a short peptidic chain, which can contribute to their interaction with the components of the solution while it can prevent their adsorption onto the membrane material; in addition, peptide-peptide interactions of hydrophobic nature could be promoted for these small molecules in an aqueous media in order to stabilize their structure. Consequently, these molecules were excluded from the membrane. Nau et al. [21] observed that the $\beta$-casein peptides $100-105$ and $108-113$, possessing low hydrophobicity and molecular mass, were found in higher concentration in the retentate $\left(\mathrm{C}_{\mathrm{p}} / \mathrm{C}_{\mathrm{r}} \approx 0.5\right)$ at neutral $\mathrm{pH}$ and low ionic strength; this indicates that some interactions can occur between these molecules and the membrane surface, but their transmission into the permeate remains higher than that of hydrophobic peptides.

The behaviour of the adsorbed and excluded peptides was confirmed by a principal component analysis. Results shown in table III revealed that the molecular mass, together with the hydrophobicity of the peptides are included in the first principal factor taking into account $72 \%$ of the differences between the peptides. In addition, the net charge of the peptides, included in the second principal component, take into account $27 \%$ of their differences. Therefore, the combination molecular mass/hydrophobicity/charge characterizes $99 \%$ of the differences between the peptides. The distribution of the peptides according to the first two principal components (figure not shown) clearly separated the group of adsorbed peptides, as well as each group of the excluded peptides, in specific zones. Thus, the combination of characteristics previously stated is determining the affinity of the peptides between the membrane or the aqueous solution.

No general trend was observed concerning the modification of the physico-chemical parameters ( $\mathrm{pH} / \mathrm{EDTA}$ ) of the TH solution, eventhough the results obtained in previous studies $[8,9,25]$ revealed that adsorption and peptide-peptide interactions were affected by the treatments. It was hypothesized that the addition of EDTA to the solution would induce an effect on basic peptides, minimizing their adsorption onto the membrane due to the electronegativity of EDTA. However, EDTA increased the adsorption of 3 of the 9 basic peptides (no 2 , 1 and 12) and only slightly decreased adsorption of peptides no 18 and 31 , while the others had the same degree of adsorption as in the samples without EDTA. Added EDTA generally seemed to modify the adsorption profile of the more hydrophilic $\left(<7 \mathrm{kcal} \cdot \mathrm{mol}^{-1}\right)$ and some of the most hydrophobic peptides (no 40,41, 42 and 44)

Table III. Results of the principal component analysis characterizing the peptides according to their molecular mass, hydrophobicity, and net charge for each principal component, and the proportion of the total eigenvalues attributable to each component.

Tableau III. Résultats de l'analyse en composantes principales caractérisant les peptides selon leur masse moléculaire, hydrophobicité et charge nette pour chaque composant principal, et la proportion des valeurs propres attribuables à chaque composant.

Characteristics

Eigenvectors

\begin{tabular}{lccc}
\cline { 2 - 4 } & Principal 1 & Principal 2 & Principal 3 \\
\hline Molecular mass & 0.671 & 0.131 & 0.730 \\
Hydrophobicity & 0.621 & 0.439 & -0.650 \\
Charge & -0.406 & 0.889 & 0.213 \\
Proportion & 0.720 & 0.271 & 0.008 \\
\hline
\end{tabular}


probably after a reorganization in the structure of the peptides upon hydrophobic and electrostatic interactions.

From these observations, it can be suggested that highly negatively charged peptides with high molecular mass are probably repelled from the membrane despite their hydrophobicity because of the strong electronegative character of the surface. In contrast, short peptides presenting charges but possessing hydrophobic amino acids are unstable in the solution and would therefore interact with other peptides. Besides, charged peptides presenting a low hydrophobicity would be stabilized in the solution by electrostatic interactions with water molecules or other charged peptides. It must be considered that the information obtained from the adsorption/desorption experiments and identification methods allowed the determination of the adsorbed peptides but after a dissociation step. In fact, the solvents used in RP-HPLC eliminate association between peptides in order to identify them. Therefore we could not determine if the peptides were adsorbed separately or in the form of peptide-peptide complexes. This could explain the discrepancies observed with the modification of $\mathrm{pH}$ and addition of EDTA.

\section{CONCLUSIONS}

As expected, adsorption of peptides onto hydrophobic PSf membranes generally increases with increasing hydrophobicity of the molecules. However, other characteristics of the peptides seemed determinant in the adsorption profile. The results suggested that the balance size/ hydrophobicity/charge of the molecule determines the attractive or repulsive interactions with the membrane, together with peptide-peptide interactions. Among the 45 adsorbed peptides, 11 of them presented specific characteristics that governed their behaviour towards the PSf membrane. It is supposed that the discrepancies observed upon modification of $\mathrm{pH}$ and addition of EDTA would be related to the conformation of casein peptides, rich in proline amino acid, and to the competition of the peptides in the interaction with the membrane surface. However, adsorption experiments should be conducted with multicharged species (e.g., poly-Lys, poly-Glu) in order to precise the effect of EDTA on the adsorption profile of the peptides. In addition, small molecules presenting adsorptive characteristics towards PSf (e.g., basic peptide with non-polar amino acid) can rapidly stabilize their structure with other molecules in TH solution and be excluded from the membrane, as well as are hydrophobic peptides of high molecular weight endowed with several negative charges.

This study was designed in order to determine preferential adsorption of casein peptides with PSf membrane surface in static conditions, in order to better understand the nature of interactions that could modify the permeability of the membrane during ultrafiltration of casein hydrolysate. Further studies on dynamic adsorption, using model solutions of peptides from different sources, would supplement the information concerning the very low permeation fluxes observed, by determining the mass balance between $\mathrm{TH}$, retentate and permeate, together with water fluxes of clean membranes, upon dynamic adsorption and after concentration. In addition, the use of analytical methods allowing the consideration of the conformation of peptides and peptidepeptide interactions at the membrane surface would give a better knowledge of the fouling phenomena.

\section{ACKNOWLEDGMENTS}

This research was funded by the FCAR. We are grateful to Osmonics who supplied the membrane material. We thank G. Henry for transforming the HPLC data for the determination of the surface areas, and Dr. M. Pouliot for his implication in the statistical analysis.

\section{REFERENCES}

[1] Bigelow C., On the average hydrophobicity of proteins and the relation between it and protein structure, J. Theoret. Biol. 16 (1967) 187-211. 
[2] Bouhallab S., Henry G., Transmission of a hydrophobic peptide through an inorganic ultrafiltration membrane: effect of membrane support, J. Membrane Sci. 104 (1995) 73-79.

[3] Brink L.E.S., Romijn D.J., Reducing protein fouling of polysulfone surfaces and polysulfone ultrafiltration membranes: Optimization of the type of presorbed layer, Desalination 78 (1990) 209-233.

[4] Brink L.E.S., Elbers S.J.G., Robbertsen T., Both P, The anti-fouling action of polymers preadsorbed on ultrafiltration and microfiltration membranes, J. Membrane Sci. 76 (1993) 281-291.

[5] Brûlé G., Roger L., Fauquant J., Piot M., Procédé de traitement d'une matière à base de caséine contenant des phosphocaséinates de cations monovalents ou leurs dérivés, produits obtenus et applications. Brevet Fr 2474829 , INPI, Paris, 1980

[6] Daufin G., Kerhervé F.L.. Aimar P., Mollé D., Léonil J., Nau F., Electrofiltration of solutions of amino acids or peptides, Lait 75 (1995) 105-115.

[7] Fritzsche A.K., Arevalo A.R., Connoly A.F., Moore M.D., Elings V., Wu C.M., The strueture and morphology of the skin of polyethersulfone ultrafiltration membranes: A comparative atomic force microscope and scanning electron microscope study, J. Appl. Polym. Sci. 45 (1992) 1945-1956.

[8] Gourley L., Britten M., Gauthier S.F., Pouliot Y., Characterization of adsorptive fouling on ultrafiltration membranes by peptides mixtures using contact angle measurements, J. Membrane Sci. 97 (1994) 283-289.

[9] Gourley L., Gauthier S.F., Pouliot Y., Separation of casein hydrolysates using polysulfone ultrafiltration membranes with $\mathrm{pH}$ and EDTA treatments applied, Lait 75 (1995) 259-269.

[10] Grosclaude F.. Genetic polymorphism in the main milk proteins in cattle. Relationship with milk yield, composition and suitability for cheese production, INRA Productions Animales 1 (1988) 5-17.

[11] Horbett T.A., Brash J.L., Proteins at interfaces II: Fundamentals and Applications, ACS, Washington, 1995

[12] Kai M., Ishii K., Tsugaya H., Miyano T., Development of polyethersulfone ultrafiltration membranes, in: Surirajan S., Matsuura T. (Eds.), Reverse osmosis and ultrafiltration, Amer. Chem. Society., Washington, 1985, p. 21.

[13] Lahl W.J., Braun S.D., Enzymatic production of protein hydrolysates for food use, Food Technol. 48 (1994) 68-71.

[14] Marshall K.R., Harper W.J., Whey protein concentrates, IDF Bulletin 233 (1988) 21.

1I5] Marshall A.D., Daufin G., Physico-chemical aspects of membrane fouling by dairy fluids, in: IDF special issue, Fouling and cleaning in pressure driven membrane processes, 9504 (1995) 8-35.
[16] Martens H. Nayes T., Multivariate calibration, in: Willy J. and Sons (éd.), Chichester, London, 1989.

[17] Maubois J.L., Mocquot G., Application of membrane ultrafiltration to preparation of various types of cheese, J. Dairy Sci., 58 (1975) 1001-1007.

[18] Meireles M., Aimar P., Sanchez V., Effect of protein fouling on the apparent pore size distribution of sieving membranes, J. Membrane Sci. 56 (1991) 13-28.

[19] Mochizuki S., Zydney A.L., Effect of protein adsorption on the transport characteristics of asymetric ultrafiltration membranes, Biotechnol. Progr. 8 (1992) 553-561.

[20] Nau F., Production et séparation par ultrafiltration de peptides trypsiques issus de caséine $\beta$ bovine, Thèse, ENSA, Rennes, France, 1991.

[21] Nau F., Kerhervé F.L., Léonil J., Daufin G., Selective separation of tryptic $\beta$-casein peptides through ultrafiltration membranes: Influence of ionic interactions, Biotechnol. Bioeng. 46 (1995) 246-253.

[22] Palecek S.P., Zydney A.L., Hydraulic permeability of protein deposits formed during microfiltration: Effect of solution $\mathrm{pH}$ and ionic strength, J. Membrane Sci. 95 (1994) 71-81.

[23] Pouliot Y., Gauthier S.F., Effect of selected physico-chemical parameters on the flux decline of casein hydrolysate on polysulfone ultrafiltration membranes, Proc ICOM'90, August 20-24, Chicago, IL, 273-275, 1990.

[24] Pouliot $Y_{\text {. }}$, Gourley L., Landry J., Fouling of ultrafiltration membranes by heat-treated whey, Eur. Dairy Mag. 12, 1992.

[25] Pouliot Y., Gauthier S.F., Bard C., Fractionation of casein hydrolysates using polysulfone ultrafiltration hollow fiber membranes, J, Membrane Sci. 80 (1993) 257-264.

[26] Pouliot M., Pouliot Y., Britten M., Ross N., Effects of $\mathrm{pH}$ and ionic environment on the permeability and rejective properties of an alumina microfiltration membrane for whey proteins, J. Membrane Sci. 95 (1994) 125-134.

[27] Swaisgood H.E., Chemistry of the caseins, in: Fox P.F. (Ed.). Advanced dairy chemistry-I: proteins, Elsevier Applied Science, NY, 1992. pp. 63-110.

[28] Tam C.M., Kutowy O., Talbot F.D.F., Retention characteristics of alcohols and sugars on polysulfone as a stationary phase with an aqueous mobile phase, Chromatographia 32 (1991) 224-228.

[29] Tanford C., Contribution of hydrophobic interactions to the stability of the globular conformation of proteins, J. Amer. Chem. Soc., 84 (1962) $4240-4247$.

[30] van der Horst H.C., Fouling of organic membranes during processing of dairy liquids, in: IDF Special issue, Fouling and cleaning in pressure driven membrane processes, 9504 (1995) pp. 36-52.

[31] van Oss C.J., Interfacial forces in aqueous media. Marcel Dekker, NY, 1994. 